\title{
Meta-analysis of the incidence of foodborne pathogens in vegetables and fruits from retail establishments in Europe
}

\author{
Beatriz Nunes Silva ${ }^{1,2}$, Vasco Cadavez ${ }^{1}$, José A Teixeira ${ }^{2}$ and \\ Ursula Gonzales-Barron ${ }^{1}$
}

In this study, a systematic review and meta-analysis were conducted to summarise available information on the occurrence of Salmonella spp. Listeria monocytogenes and shigatoxin-producing Escherichia coli (STEC) in fruits and vegetables sold at retail establishments in several European countries. Overall, L. monocytogenes was the main pathogen detected in all kinds of vegetables, packaged or not $(3.4 \%$; 95\% Cl: 2.1-5.4\%) with Salmonella spp. being the pathogen of lowest incidence (0.9\%; 95\% Cl: 0.5-1.2\%). The pooled occurrence rate of pathogens in either packed or unpacked vegetables was estimated at $1.9 \%$ (95\% Cl: $1.2-3.1 \%)$, with $2.1 \%$ of prevalence $(95 \% \mathrm{Cl}: 1.3-3.4 \%)$ for unpacked vegetables and $1.7 \%$ (95\% Cl: $0.9-2.9 \%)$ for packed ones. For the three pathogens, the category of spices and herbs was the most frequently contaminated with pathogens, whereas salads presented the lowest occurrence. The vegetable category with highest incidence of Salmonella spp. (1.7\%; 95\% Cl: $0.7-4.1 \%)$ and L. monocytogenes (2.2\%; $95 \% \mathrm{Cl}: 1.0-4.7 \%)$ is leafy greens whilst STEC is more frequently recovered from sprouts $(1.9 \%$; $95 \% \mathrm{Cl}: 0.5-5.9 \%)$. In the case of fruits, the pooled prevalence estimates for Salmonella spp., L. monocytogenes and STEC were $1.60 \%$ (0.54\%; 95\% Cl: 0.55-4.60\%), 1.91\% (0.50\%; 95\% Cl: $0.93-3.88 \%)$ and $4.71 \%$ (1.52\%; 95\% Cl: $1.73-12.2 \%)$, correspondingly.

\footnotetext{
Addresses

${ }^{1}$ CIMO Mountain Research Centre, School of Agriculture, Polytechnic Institute of Braganza, Portugal

${ }^{2}$ University of Minho, Braga, Portugal

Corresponding author: Gonzales-Barron, Ursula (ubarron@ipb.pt)

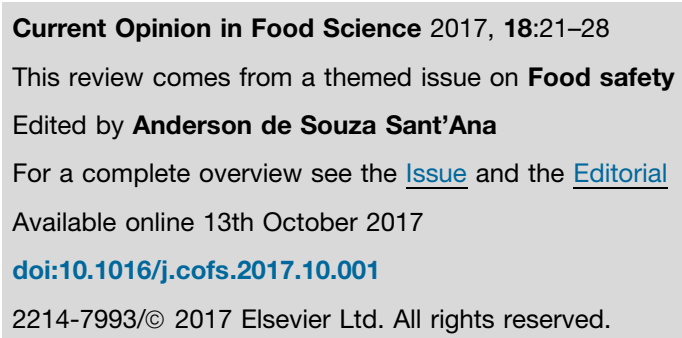

\section{Introduction}

Compared to previous decades, today's society is increasingly more aware and concerned about their health and foods' impact on it, which has had two main consequences: the increase of vegetable and fruit consumption and the amplified offer of these products in retail establishments in varied forms (fresh, pre-washed, frozen, dried, etc.). However, these products can be contaminated by pathogens such as Salmonella spp., Listeria monocytogenes or shigatoxin-producing Escherichia coli (STEC), therefore, promoting the occurrence of foodborne diseases, a significant and widespread global public health threat. According to the European Food Safety Authority, in the European Union (EU) alone, over 320000 human cases are reported each year, although the real figure is estimated to be much higher $\left[1^{\bullet \bullet}\right]$. In 2013, Salmonella was the most frequently detected causative agent of foodborne outbreaks (representing 22.5\% of total outbreaks). In the same year, 73 outbreaks of VTEC and 13 of Listeria were also reported, thus demonstrating the impact these pathogens on public health $\left[1^{\bullet \bullet}\right]$.

Fresh fruits and vegetables carry natural non-pathogenic microorganisms, yet, during growth, harvest, transportation and further handling, these products can become contaminated with pathogens [2]. During growth, contamination can arise from the use of organic fertilisers and poor quality of the irrigation water; during harvest and transportation, the use of contaminated equipment and containers, as well as poor storage conditions, with excessive humidity and temperatures, increase bacteria's opportunities of growth; during post-harvest, poor handling procedures may cause damage to the produce, thus opening a window for contamination if hygienic conditions from operators and equipment are not satisfactory.

The objective of this study was to summarise the incidences of Salmonella, L. monocytogenes and STEC in fruits and vegetables sold at European retail establishments and to present an overview of such contamination, broken down by type of produce and European region. In order to do so, separate multilevel meta-analysis model were adjusted.

\section{Methodology}

Meta-analysis is a statistical analysis of a vast collection of results from published primary studies, whose main 
purpose is to integrate and interpret the findings to achieve conclusions that the individual studies alone would not show clearly $\left[3^{\bullet \bullet}\right.$. In this study, the population is defined as fruits and vegetables surveyed at retail establishments in Europe while the measured outcome is the detection of pathogens. Literature search was conducted using Scopus and ISI Web of Knowledge and Web of Science databases for English written papers indexed since 2000 in Europe. For the searches, a formula that combined terms regarding the existence (prevalence, incidence, occurrence, concentration, count, microbiological quality) of pathogens (Salmonella, L. monocytogenes and E. coli) in the target products (fruit, produce, vegetable, leafy, seed, legume, spice, oilseed, nut, sprout, ready-toeat, RTE) was applied, making proper use of the AND and OR logical connectors.

A parameterisation of the effect size was then determined to allow direct comparison and summation of primary studies. Because the occurrence of microbial hazards in fruits/vegetables is a binary trait (a sample tests either positive or negative for the pathogen), the parameter to measure the effect size $\theta$ was the raw proportion $p$ (number of successes or positive samples, $s$, divided by the total sample size, $n$ ). In order to restrict the range of the effect size or pathogen's incidence from 0 to 1 , and to stabilise the variance, the logit transformation of $p$ was chosen as the effect size measure $\theta\left[4^{\bullet \bullet}\right]$.

After assessing all the information from the recovered publications, fifty-three primary studies $\left[1^{\bullet \bullet}, 5-33,34^{\bullet}, 35\right.$ $\left.42,43^{\circ}, 44^{\bullet}, 45,46-55,56^{\circ}\right]$ published from 2001 until May 2017 were considered appropriate for inclusion for having used approved microbiological methods and presenting sufficient and extractable data. From each study, the total number $n$ and number of positive samples $s$ were extracted, as well as the country, year of the survey, packed/unpacked condition, food class, sample weight ( $\mathrm{g}$ ) for microbiological analysis and microbiological method. The fruit classes defined were: berries, drupes, nuts, pepo, pome, tropical and non-classified (assorted fruits or non-specified), while vegetables were classified as: leafy greens, lettuce only, spices and herbs, salads, sprouts and non-classified vegetables (assorted vegetables or non-specified).

Several multilevel random-effect meta-analysis models were fitted to appropriate data subsets in order to estimate overall or pooled incidences for: first, pathogens in packed and unpacked vegetables as a whole; second, pathogens in packed and unpacked disaggregated vegetable classes; third, pathogens by vegetable class; fourth, pathogens by country; fifth, pathogens by European region and sixth, pathogens in fruits. For a detailed explanation on multilevel meta-analysis modelling for prevalence data, refer to

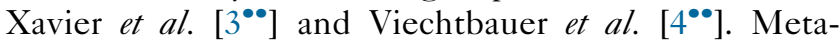
analysis models and graphs were built in R Studio version 1.0.136 using the 'metafor' package.

\section{Results and discussion}

Following study quality checking, a total of 384 observations of positive and negative results of incidence of foodborne pathogens in vegetables and 69 observations in fruits were excerpted. Information on the distribution of observations by fruit and vegetable class can be found in Table 1. A breakdown of number of primary studies by ranges of publication year is shown in Table 2. From 2013 onwards, more surveys on the incidence of pathogens in fruits and vegetables have been published in comparison to five-year spans between 2001 and 2012.

\section{Incidence of pathogens in packed and unpacked vegetables at retail level}

For this meta-analysis, only the categories Salads, Spices and Herbs, Sprouts and Non-classified Vegetables were

Table 1

Number of observations $(n)$ of foodborne pathogens in fruits and vegetables by class and by packaging type ( $n$; packed/unpacked) extracted from published survey studies

\begin{tabular}{lllll}
\hline & Type of product & Salmonella spp. & L. monocytogenes & STEC \\
\hline Fruits & Berries & $3 ; 0 / 3$ & $3 ; 0 / 3$ & $4 ; 0 / 4$ \\
& Drupes & 0 & $1 ; 0 / 1$ & 0 \\
& Nuts & $5 ; 0 / 5$ & 0 & $5 ; 0 / 5$ \\
& Pepo & $4 ; 0 / 4$ & $5 ; 0 / 5$ & 0 \\
Pome & $2 ; 0 / 2$ & $1 ; 0 / 1$ & $1 ; 0 / 1$ \\
& Tropical & $3 ; 0 / 3$ & $3 ; 0 / 3$ & 0 \\
& Non-classified & $6 ; 1 / 5$ & $12 ; 3 / 9$ & $11 ; 2 / 9$ \\
Tegetables & Total & $23 ; 1 / 22$ & $25 ; 3 / 22$ & $21 ; 2 / 19$ \\
& Leafy Greens & $15 ; 0 / 15$ & $21 ; 5 / 16$ & $17 ; 0 / 17$ \\
& Lettuce & $14 ; 1 / 13$ & $16 ; 0 / 16$ & $16 ; 0 / 16$ \\
& Salads & $21 ; 13 / 8$ & $33 ; 24 / 9$ & $12 ; 7 / 5$ \\
& Spices \& herbs & $64 ; 5 / 59$ & $13 ; 6 / 7$ & $11 ; 2 / 9$ \\
& Sprouts & $13 ; 2 / 11$ & $10 ; 3 / 7$ & $22 ; 3 / 19$ \\
& Non-classified & $10 ; 3 / 7$ & $21 ; 9 / 12$ & $15 ; 8 / 47$ \\
& Total & $137 ; 24 / 113$ & $114 ; 47 / 67$ & $133 ; 20 / 113$ \\
\hline
\end{tabular}




\section{Table 2}

\begin{tabular}{ll}
$\begin{array}{l}\text { Number of primary studies retrieved sorted by publication year } \\
\text { range }\end{array}$ & No. primary studies \\
\hline Publication year & 9 \\
\hline$[2001-2004]$ & 12 \\
{$[2005-2008]$} & 12 \\
{$[2009-2012]$} & 20 \\
\hline $2013-2017]$ & \\
\hline
\end{tabular}

used, since the classes Leafy Greens and Lettuce did not present sufficient data for the two packaging conditions to allow comparisons. For that reason, only 40 primary studies were used, which furnished a total of 284 observations. In most of the data (78\%), there was no indication as to the type of packaging, while in the other $22 \%$, authors stated that modified atmosphere packaged produce was sampled.

Meta-analysis summarised the global mean incidence of pathogens in either packed or unpacked vegetables to be $1.93 \%$ (95\% CI: $1.19-3.11 \%$ ), with unpacked vegetables having higher prevalence of pathogens $(2.07 \%$; $95 \% \mathrm{CI}$ : $1.26-3.37 \%)$ than packed ones $(1.68 \%$; $95 \%$ CI: $0.97-$ $2.89 \%)$. Pooled prevalence estimates for this meta-analysis are compiled in Table 3. L. monocytogenes is the pathogen of greatest concern as it bears the highest pooled incidences in packed vegetables $(2.49 \%$; $95 \%$ CI: $1.50-4.12 \%)$ and unpacked vegetables $(4.42 \%$; $95 \%$ CI: $1.79-10.53 \%)$. Salmonella spp. has the lowest prevalence in either packed $(0.55 \%$; $95 \%$ CI: $0.31-0.97 \%)$ or unpacked vegetables $(0.98 \%$; $95 \%$ CI: $0.37-2.61 \%)$. For each of the three pathogens under study, the unpacked/ bulk vegetables presented consistently higher pooled prevalences than the packed vegetables (Table 3).

Among the four vegetable categories, unpacked or packed, Spices and Herbs (2.08\%; 95\% CI: $1.15-3.75 \%)$ were the most frequently contaminated by either STEC, L. monocytogenes or Salmonella spp. disregarding the Nonclassified category (for being unknown and assorted) while Salads were the least contaminated $(1.49 \%$; $95 \%$ CI: $0.85-2.58 \%$ ). A breakdown of these results by

\section{Table 3}

Meta-analysis of the incidence of pathogens in packed and unpacked vegetables surveyed at retail in Europe

\begin{tabular}{llll}
\hline & Microorganism & $\begin{array}{c}\text { Pooled } \\
\text { prevalence (\%) }\end{array}$ & $\begin{array}{c}95 \% \mathrm{Cl} \text { pooled } \\
\text { prevalence (\%) }\end{array}$ \\
\hline Packed & Salmonella spp. & 0.545 & {$[0.305-0.971]$} \\
& L. monocytogenes & 2.491 & {$[1.496-4.122]$} \\
& STEC & 1.235 & {$[0.682-2.226]$} \\
Unpacked & Salmonella spp. & 0.983 & {$[0.366-2.614]$} \\
& L. monocytogenes & 4.424 & {$[1.789-10.53]$} \\
& STEC & 2.215 & {$[0.817-5.864]$} \\
\hline
\end{tabular}

\section{Table 4}

Meta-analysis of the incidence of pathogens in different vegetable categories, either packed or unpacked, surveyed at retail in Europe

\begin{tabular}{lll}
\hline & $\begin{array}{c}\text { Pooled } \\
\text { prevalence (\%) }\end{array}$ & $\begin{array}{l}95 \% \mathrm{Cl} \text { pooled } \\
\text { prevalence (\%) }\end{array}$ \\
\hline Salads & 1.488 & {$[0.853-2.583]$} \\
Packed & 1.464 & {$[0.815-2.615]$} \\
Unpacked & 1.526 & {$[0.827-2.800]$} \\
Spices \& Herbs & 2.084 & {$[1.148-3.754]$} \\
Packed & 2.001 & {$[0.624-6.225]$} \\
Unpacked & 2.087 & {$[0.633-6.650]$} \\
Sprouts & 1.643 & {$[0.849-3.154]$} \\
Packed & 1.597 & {$[0.494-5.035]$} \\
Unpacked & 1.665 & {$[0.501-5.383]$} \\
Non-classified veg. & 2.916 & {$[1.645-5.100]$} \\
Packed & 2.817 & {$[0.931-8.204]$} \\
Unpacked & 2.936 & {$[0.945-8.751]$} \\
\hline
\end{tabular}

Table 5

Meta-analysis of the incidence of pathogens in salads, spices and herbs, sprouts and undefined vegetables surveyed at retail in Europe

\begin{tabular}{lll}
\hline Microorganism & \multicolumn{1}{c}{$\begin{array}{c}\text { Pooled } \\
\text { prevalence (\%) }\end{array}$} & $\begin{array}{l}\text { 95\% Cl pooled } \\
\text { prevalence (\%) }\end{array}$ \\
\hline STEC & 1.905 & {$[1.129-3.197]$} \\
L. monocytogenes & 3.399 & {$[2.108-5.435]$} \\
Salmonella spp. & 0.860 & {$[0.520-1.419]$} \\
\hline
\end{tabular}

packaging condition is shown in Table 4 . When all incidence measures across pathogens were brought together, L. monocytogenes was found to be the main one in all four vegetable categories (3.40\%; 95\% CI: $2.11-5.44 \%$ ) while Salmonella spp. presented the lowest frequency of detection $(0.86 \%$; $95 \%$ CI: $0.52-1.21 \%$ ) (Table 5$)$.

\section{Incidence of Salmonella spp., L. monocytogenes and STEC in vegetables at retail level}

A meta-analysis on Salmonella spp. in packed and unpacked vegetables using vegetable class as moderator revealed high prevalence of this pathogen in Leafy Greens (1.74\%; 95\% CI: $0.74-4.07 \%)$ compared to the other categories under study (pooled prevalences from 0.47 to $1.24 \%$; Table 6 ). The food class with the lowest incidence of this pathogen was Salads $(0.47 \%$; $95 \%$ CI: $0.24-0.934 \%$; Table 6). In relation to L. monocytogenes, disregarding the Non-classified vegetables, Leafy Greens presented the highest incidence $(2.25 \%$; 95\% CI: $1.05-$ $4.74 \%)$. On the opposite side, the category with lowest incidence of L. monocytogenes turned out to be Spices and Herbs (1.06\%; 95\% CI: 0.43-2.61\%; Table 6). Excluding the Non-classified category, Sprouts presented the highest pooled prevalence of STEC $(1.86 \%$; $95 \%$ CI: $0.56-$ $5.96 \%$; Table 6), while Lettuce presented the lowest frequency of detection $(0.67 \%$; 95\% CI: $0.19-2.32 \%$; Table 6). 


\begin{tabular}{|c|c|c|c|}
\hline \multicolumn{4}{|c|}{$\begin{array}{l}\text { Meta-analysis of the incidence of Salmonella spp., L. monocy- } \\
\text { togenes and STEC in different vegetable categories surveyed at } \\
\text { retail in Europe }\end{array}$} \\
\hline Microorganism & Product & $\begin{array}{l}\text { Pooled } \\
\text { prevalence } \\
(\%)\end{array}$ & $\begin{array}{l}95 \% \mathrm{Cl} \text { pooled } \\
\text { prevalence } \\
(\%)\end{array}$ \\
\hline Salmonella spp. & $\begin{array}{l}\text { Leafy Greens } \\
\text { Lettuce } \\
\text { Salads } \\
\text { Spices \& herbs } \\
\text { Sprouts } \\
\text { Non-classified veg. }\end{array}$ & $\begin{array}{l}1.742 \\
1.168 \\
0.471 \\
1.241 \\
0.593 \\
0.955\end{array}$ & $\begin{array}{l}{[0.737-4.066]} \\
{[0.469-2.877]} \\
{[0.237-0.933]} \\
{[0.644-2.380]} \\
{[0.248-1.413]} \\
{[0.393-2.300]}\end{array}$ \\
\hline L. monocytogenes & $\begin{array}{l}\text { Leafy greens } \\
\text { Lettuce } \\
\text { Salads } \\
\text { Spices \& herbs } \\
\text { Sprouts } \\
\text { Non-classified veg. }\end{array}$ & $\begin{array}{l}2.245 \\
1.796 \\
1.752 \\
1.063 \\
1.495 \\
3.340\end{array}$ & $\begin{array}{l}{[1.048-4.744]} \\
{[0.842-3.791]} \\
{[0.898-3.388]} \\
{[0.429-2.608]} \\
{[0.547-4.019]} \\
{[1.659-6.609]}\end{array}$ \\
\hline STEC & $\begin{array}{l}\text { Leafy greens } \\
\text { Lettuce } \\
\text { Salads } \\
\text { Spices \& herbs } \\
\text { Sprouts } \\
\text { Non-classified veg. }\end{array}$ & $\begin{array}{l}1.360 \\
0.672 \\
0.739 \\
1.012 \\
1.858 \\
4.335\end{array}$ & $\begin{array}{l}{[0.412-4.396]} \\
{[0.192-2.317]} \\
{[0.237-2.280]} \\
{[0.252-3.967]} \\
{[0.562-5.963]} \\
{[1.132-15.21]}\end{array}$ \\
\hline
\end{tabular}

Funnel plots of the incidence of the three pathogens in these six vegetable classes are displayed in Figure 1. None of the funnel plots showed strong evidence of publication bias, since there were no blank areas at the bottom of the funnels. However, the top of the funnel plots, in all cases, displays a large blank area, which hints the lack of published surveys with large sample size. That might influence the results, since it is likely that a small sample size will not have the statistical power to detect a positive food unit if the true prevalence is very low $\left[3^{\bullet \bullet}\right]$. Hence, in microbiological surveys of absence/ presence of pathogens in foods, a large sample size should be used $\left[3^{\circ}\right.$ ]. In funnel plot $\mathrm{C}$, most studies are concentrated to the right (indicating that most primary studies report positive results of STEC), which is consistent with the possibility that studies that failed to have positive results are missing.

\section{Incidence of pathogens in vegetables at retail level by European country and region}

From the initial subset of data (six vegetable categories), studies from countries with at least 8 observations were selected, thus creating a new subset of 340 studies from 12 countries. The number of observations and the estimated pooled incidences of all three pathogens in the six vegetables by country are presented in Table 7 . This meta-analysis suggested that the highest overall frequencies of detection of pathogens in vegetables were reported in studies from Spain (8.94\%; 95\% CI: 6.66-11.90) and Czech Republic (6.89\%; 95\% CI: 4.29-10.89). On the other hand, the UK $(0.27 \%$; $95 \%$ CI: $0.16-0.43 \%)$ and Norway ( $0.87 \%$; $95 \%$ CI: $0.45-1.69 \%)$ reported the lowest occurrence of pathogens.

Figure 1

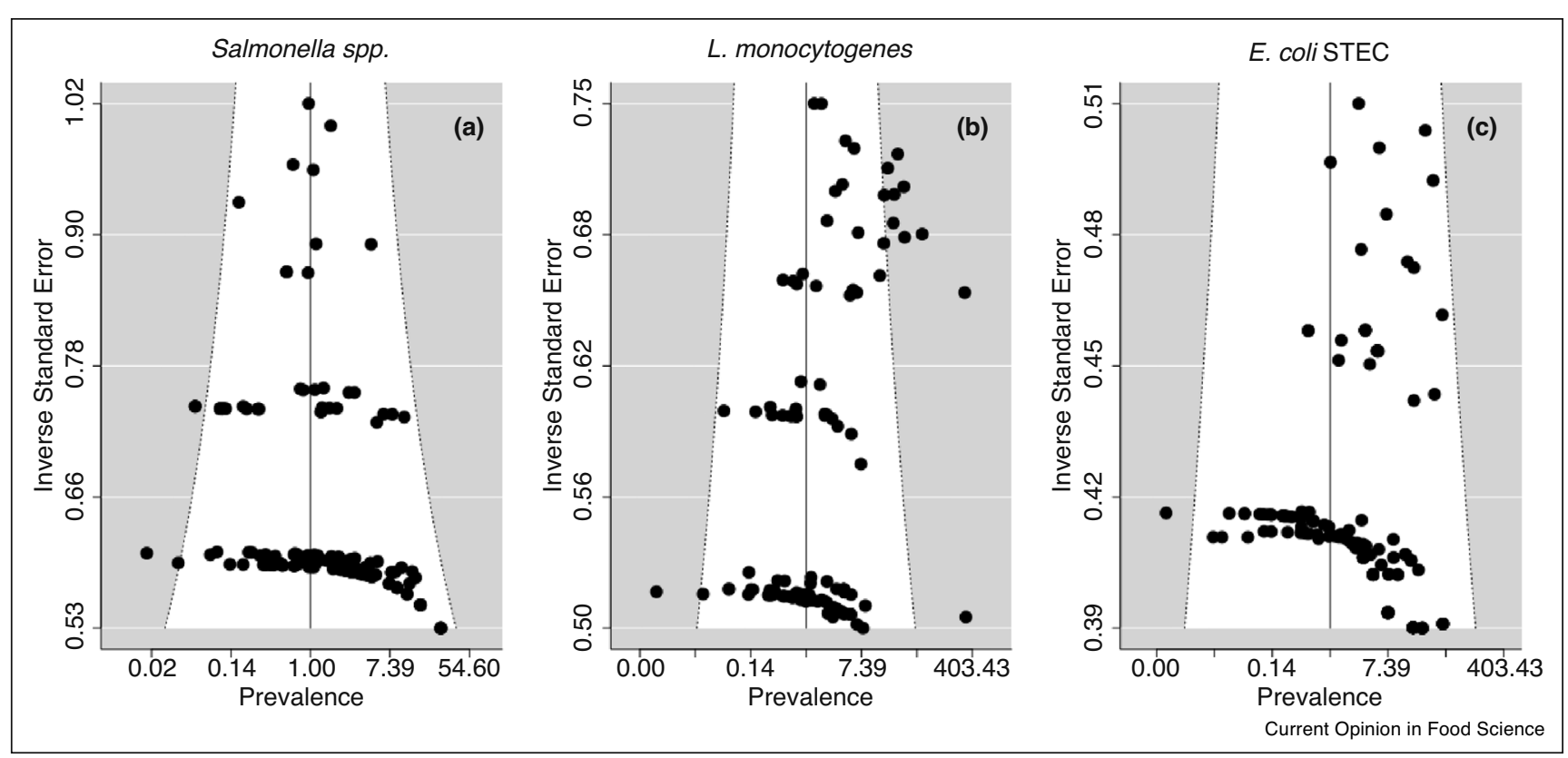

Funnel plots of the meta-analyses of Salmonella spp. (a), L. monocytogenes (b); and STEC (c) in vegetables - encompassing leafy greens, lettuce, salads, spices \& herbs, sprouts and non-classified vegetables-surveyed at retail in Europe. 
Table 7

\begin{tabular}{|c|c|c|c|}
\hline Country & $\begin{array}{c}\text { Pooled } \\
\text { prevalence (\%) }\end{array}$ & $n$ & $\begin{array}{c}95 \% \mathrm{Cl} \text { of } \\
\text { pooled prevalence }(\%\end{array}$ \\
\hline Albania & 2.600 & 8 & [0.816-7.965] \\
\hline Austria & 4.180 & 18 & [1.969-8.654] \\
\hline Belgium & 1.006 & 9 & [0.458-2.193] \\
\hline Czech Republic & 6.891 & 41 & {$[4.291-10.88]$} \\
\hline Ireland & 5.173 & 62 & [3.509-7.565] \\
\hline Italy & 0.939 & 24 & [0.485-1.810] \\
\hline Norway & 0.871 & 24 & [0.448-1.687] \\
\hline Portugal & 2.384 & 14 & [1.056-5.293] \\
\hline Spain & 8.938 & 77 & [6.657-11.90] \\
\hline Sweden & 2.202 & 9 & [0.848-5.597] \\
\hline Turkey & 3.641 & 24 & [2.113-6.206] \\
\hline United Kingdom & 0.265 & 30 & [0.163-0.430] \\
\hline
\end{tabular}

A separate meta-analysis by region revealed that the Northern European regions present the lowest pooled prevalence of pathogens in vegetables $(1.10 \%$; 95\% CI: 0.46-2.6\%). Since most cases of human salmonellosis, listeriosis and STEC infections are reported during the summer [57-59], this might indicate that lower temperatures during other seasons play some role in reducing the viability of pathogens. As a result, it is likely that in Northern European countries, whose average temperatures (per year) are lower, the growth of microorganisms on vegetables on farms is retarded. This, in turn, would lead to lower concentrations at the harvest and retail stages in comparison to the Southern European countries. In fact, according to a study appraising the impact of climatic determinants on foodborne diseases, elevated ambient temperatures were proven to augment the replication cycles of most foodborne pathogens [60], a conclusion that supports the hypothesis above.

\section{Incidence of pathogens in fruits at retail level}

For fruits, a meta-analysis was performed with no distinction of classes, since the data available within categories were very small (Table 1). On meta-analysis, the prevalence of Salmonella spp. in fruits is $1.60 \%$ (95\% CI: 0.55 $4.60 \%$ ), whereas that of L. monocytogenes is slightly higher at $1.91 \%$ (95\% CI: $0.93-3.88 \%$ ). Interestingly, unlike the results for vegetables, STEC was the pathogen of greatest incidence in fruits, presenting a pooled incidence of $4.71 \%$ (95\% CI: $1.73-12.2 \%$ ). Forest plots were built to gather the incidence measures extracted from primary studies for Salmonella spp. (Figure 2), L. monocytogenes (Figure 3) and STEC (Figure 4) in fruits. None of the forest plots signalled strong heterogeneity in pathogens' prevalence among studies, although, due to the small sample size of some studies, wide confidence intervals were produced. The limited number of studies available for the fruits meta-analysis may have biased the results, so these pooled prevalences must be interpreted with caution.
Figure 2

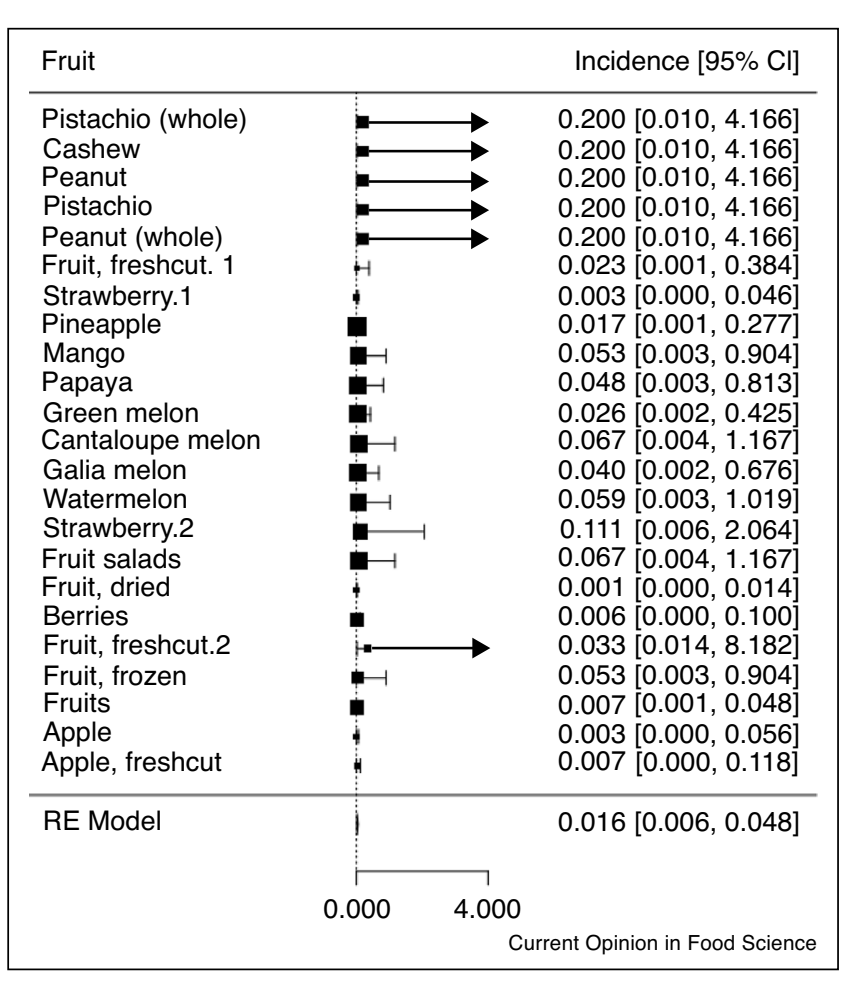

Forest plot of the incidence of Salmonella spp. in fruits surveyed at retail in European establishments.

Results from the EFSA report indicate that, amongst raw and minimally processed foods of non-animal origin, leafy greens, bulb and stem vegetables, tomatoes, melons, fresh pods, legumes, sprouted seeds and berries pose the highest risks in the EU [61]. According to this EU report, the top-ranking combinations of foods and pathogens are Salmonella and leafy greens eaten raw; Salmonella and bulb and stem vegetables; Salmonella and tomatoes; Salmonella and melons; and pathogenic E. coli and fresh pods, legumes or grains [61]. Although the food categories of highest prevalence in this study are in accordance with EFSA's results, it is interesting that, in our meta-analysis, Salmonella spp. emerged, in all cases, as the pathogen of lowest incidence. The reason for these findings could be that, in our meta-analysis, only the incidence in vegetables was used to draw conclusions, while the risk ranking combinations defined by EFSA were calculated by taking into account also the number of outbreaks in the EU population. With Salmonella stated as the most frequently detected causative agent in foodborne outbreaks occurred in $2013\left[1^{\bullet \bullet}\right]$, it is expected that this pathogen turned out as the most important in the EFSA's top-ranking combinations.

As most fruits and some vegetables can be eaten raw by the consumers after washing, a step sometimes disregarded or not properly performed, it is important for 
Figure 3

\begin{tabular}{|c|c|c|}
\hline Fruit & {$[0.010,4.166]$} & Incidence $[95 \% \mathrm{Cl}]$ \\
\hline $\begin{array}{l}\text { Fruit, freshcut. } 1 \\
\text { Strawberry.1 } \\
\text { Pineapple } \\
\text { Mango } \\
\text { Papaya } \\
\text { Green melon } \\
\text { Cantaloupe melon } \\
\text { Galia melon } \\
\text { Watermelon } \\
\text { Strawberry.2 } \\
\text { Fruit salads.1 } \\
\text { Fruit, dried.1 } \\
\text { Berries } \\
\text { Fruit, freshcut.2 } \\
\text { Fruit, frozen } \\
\text { Fruits.1 } \\
\text { Green Table Olives } \\
\text { Fruit salads.2 } \\
\text { Melon } \\
\text { Fruits.2 } \\
\text { RTE Fruit puree.1 } \\
\text { RTE Fruit puree.2 } \\
\text { Apple, freshcut } \\
\text { Fruits.3 } \\
\text { Fruit, dried.2 }\end{array}$ & i-1 & $\begin{array}{l}0.023[0.001,0.384] \\
0.006[0.001,0.042] \\
0.017[0.001,0.277] \\
0.053[0.003,0.904] \\
0.048[0.003,0.813] \\
0.026[0.002,0.425] \\
0.067[0.004,1.167] \\
0.040[0.002,0.676] \\
0.059[0.003,1.019] \\
0.111[0.006,2.064] \\
0.067[0.004,1.167] \\
0.001[0.000,0.014] \\
0.013[0.002,0.091] \\
0.333[0.014,8.182] \\
0.053[0.003,0.904] \\
0.003[0.000,0.053] \\
0.111[0.014,0.877] \\
0.006[0.000,0.100] \\
0.006[0.000,0.100] \\
0.006[0.000,0.097] \\
0.333[0.014,8.182] \\
0.030[0.002,0.505] \\
0.007[0.000,0.118] \\
0.043[0.003,0.738] \\
0.059[0.003,1.019]\end{array}$ \\
\hline \multirow[t]{2}{*}{ RE Model } & 1 & $0.020[0.009,0.040]$ \\
\hline & $\begin{array}{r}4.000 \\
C u\end{array}$ & ent Opinion in Food Science \\
\hline
\end{tabular}

Forest plot of the incidence of $L$. monocytogenes in fruits surveyed at retail in European establishments.

the food industry to assess the microbial content of its products in order to protect consumers' health and reduce the risk of food poisoning. Being responsible for providing safe food, processing plants should reinforce the implementation of good hygiene practice sand monitoring plans, proper maintenance of the cold chain (from factory to retail) and the use of visible labelling for use-by date. Simultaneously, the food industry should be encouraged to be compliant with guidelines and rules created by countries' governments and food safety organisations.

Despite industries' responsibility to provide safe food, the consumer can also take preventive measures to avoid pathogens in fruits and vegetables, such as: scrubbing the skin of pepos (i.e. cantaloupe and other melons) with water and a brush before cutting it; washing the fruit or vegetable even if it will be peeled; washing fruits and vegetables with running water while using some friction (instead of soaking); using clean utensils and work surfaces; washing hands after handling raw products and avoiding cross-contamination. Consumers also need to be aware of the proper storage of foods: the refrigerator, for instance, must be kept below $5^{\circ} \mathrm{C}$. Cooking is another way to attain safer foods, but a certain temperature must be achieved to eliminate pathogenic bacteria. For Salmonella spp. and L. monocytogenes, $66^{\circ} \mathrm{C}$ and $77^{\circ} \mathrm{C}$, respectively, must be reached while for STEC,
Figure 4

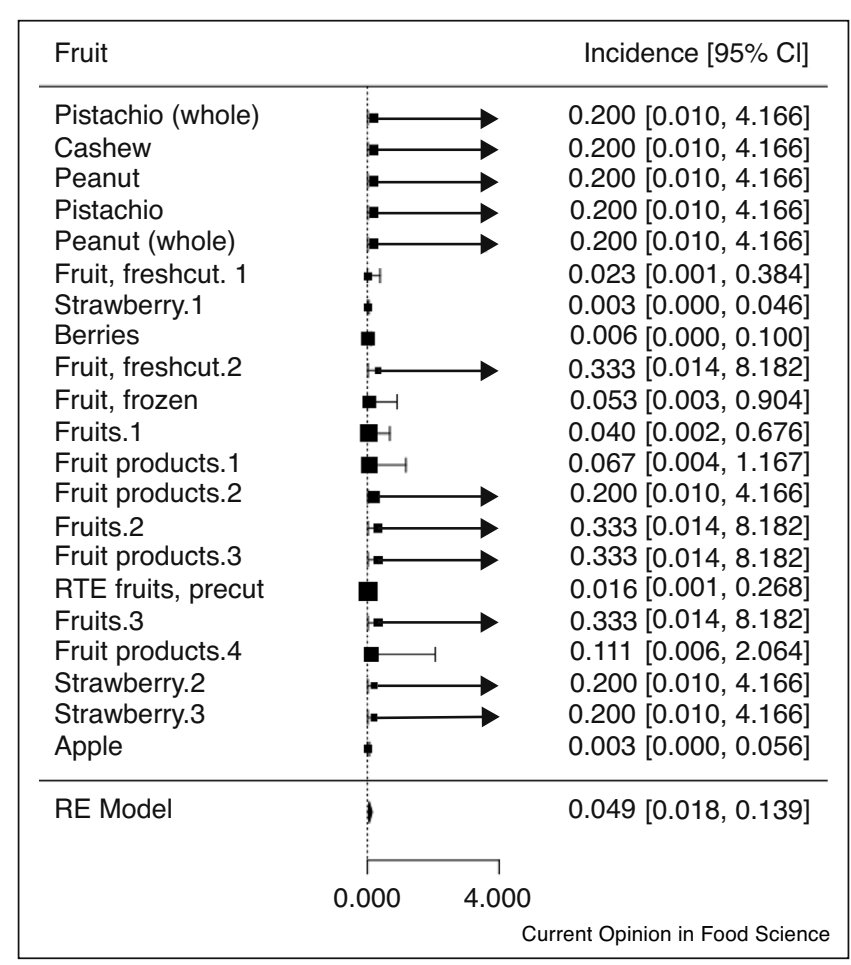

Forest plot of the incidence of shigatoxin-producing $E$. coli in fruits surveyed at retail in European establishments.

temperatures around $69^{\circ} \mathrm{C}$ are expected to provide at least a $5-\log$ reduction [62].

\section{Concluding remarks}

Meta-analyses on prevalence data from surveys in Europe indicated that L. monocytogenes is currently the main pathogen contaminating vegetables, while STEC is the one most frequently detected in fruits. Further research focused on reducing the levels of pathogens in fruits and vegetables by minimal processing technologies should be undertaken. In addition, challenge tests and predictive microbiology are scientific resources that researchers and food companies can take up in order to guarantee safe products and prevent outbreaks. As control of pathogens in fruits and vegetables sold at retail may not be easy, the food industry and food safety agencies must continue taking surveillance and training actions to guarantee products' quality and the well-being of consumers. Finally, the consumers themselves must be educated on how to properly handle, wash and store vegetables and fruits prior to consumption.

\section{Acknowledgements}

Dr. Gonzales-Barron wishes to acknowledge the financial support provided by the Portuguese Foundation for Science and Technology (FCT) through the award of a five-year Investigator Fellowship (IF) in the mode of Development Grants (IF/00570). 


\section{References and recommended reading}

Papers of particular interest, published within the period of review, have been highlighted as:

- of special interest

$\bullet$ of outstanding interest

1. EFSA: The European Union summary report on trends and

-. sources of zoonoses, zoonotic agents and food-borne outbreaks in 2013. EFSA J 2015.

A very comprehensive report including prevalence of pathogens in foods of diverse origin as well as causative agents of outbreaks.

2. Ogundipe FO, Bamidele FA, Adebayo-Oyetoro AO, Ogundipe OO, Tajudeen OK: Incidence of Bacteria with Potential Public Health Implications in Raw Lycopersicon esculentum (Tomato) sold in Lagos State, Nigeria. NIFOJ 2012, 30:106-113.

3. Xavier C, Gonzales-Barron U, Paula V, Estevinho L, Cadavez V:

- Meta-analysis of the incidence of foodborne pathogens in Portuguese meat and their products. Food Res Int 2014. $55: 311-323$

All equations for meta-analysis on incidence data are presented in this article.

4. Viechtbauer $\mathbf{W}$ : Conducting meta-analyses in $\mathbf{R}$ with the -. metafor package. J Stat Softw 2010, 36:1-48.

Most of the capabilities of the metafor package are explained in great detail and with illustrations.

5. Abadias M, Canamas TP, Asensio A, Anguera M, Vinas I: Microbial quality of commercial 'Golden Delicious' apples throughout production and shelf-life in Lleida (Catalonia, Spain). Int J Food Microbiol 2006, 108:404-409.

6. Abadias M, Usall J, Anguera M, Solson C, Vinas I: Microbiological quality of fresh, minimally-processed fruit and vegetables, and sprouts from retail establishments. Int J Food Microbiol 2008 , 123:121-129.

7. Angelidis AS, Chronis EN, Papageorgiou DK, Kazakis II, Arsenoglou KC, Stathopoulos GA: Non-lactic acid, contaminating microbial flora in ready-to-eat foods: a potential food-quality index. Food Microbiol 2006, 23:95-100.

8. Badosa E, Trias R, Pares D, Pla M, Montesinos E: Microbiological quality of fresh fruit and vegetable products in Catalonia (Spain) using normalised plate-counting methods and real time polymerase chain reaction (QPCR). J Sci Food Agric 2008, 88:605-611.

9. Becker B, Schuler S, Lohneis M, Sabrowski A, Curtis GD, Holzapfel WH: Comparison of two chromogenic media for the detection of Listeria monocytogenes with the plating media recommended by EN/DIN 11290-1. Int J Food Microbiol 2006, 109:127-131.

10. Caggia C, Randazzo CL, Di Salvo M, Romeo F, Giudici P: Occurrence of Listeria monocytogenes in green table olives. $J$ Food Prot 2004, 67:2189-2194.

11. Campos J, Mourão J, Pestana N, Peixe L, Novais C, Antunes P: Microbiological quality of ready-to-eat salads: an underestimated vehicle of bacteria and clinically relevant antibiotic resistance genes. Int J Food Microbiol 2013, 166:464 470.

12. Candlish AAG, Pearson SM, Aidoo KE, Smith JE, Kelly B, Irvine H: A survey of ethnic foods for microbial quality and aflatoxin content. Food Addit Contam 2001, 18:129-136.

13. Caponigro V, Ventura M, Chiancone I, Amato L, Parente E, Piro F Variation of microbial load and visual quality of ready-to-eat salads by vegetable type, season, processor and retailer. Food Microbiol 2010, 27:1071-1077.

14. Cardamone C, Aleo A, Mammina C, Oliveri G, Di Noto AM: Assessment of the microbiological quality of fresh produce on sale in Sicily, Italy: preliminary results. J Biol Res Thessalon 2015, 22:1-6.

15. Cetinkaya F, Cibik R, Soyutemiz GE, Ozakin C, Kayali R, Levent B: Shigella and Salmonella contamination in various foodstuffs in Turkey. Food Control 2008, 19:1059-1063.
16. Cetinkaya F, Mus TE, Yibar A, Guclu N, Tavsanli H, Cibik R: Prevalence, serotype identification by multiplex polymerase chain reaction and antimicrobial resistance patterns of Listeria monocytogenes isolated from retail foods. J Food Saf 2014, 34:42-49.

17. Van Coillie E, Werbrouck H, Heyndrickx M, Herman L, Rijpens N: Prevalence and typing of Listeria monocytogenes in ready-toeat food products on the Belgian market. J Food Prot 2004, 67:2480-2487.

18. Coroneo V, Sanna A, Danjou F, Caboni P, Dessi S: Influence of season on microbiological loads in ready-to-eat vegetables. Ital J Food Sci 2010, 22:205-209.

19. Delbeke S, Ceuppens S, Jacxsens L, Uyttendaele M: Microbiological analysis of pre-packed sweet basil (Ocimum basilicum) and coriander (Coriandrum sativum) leaves for the presence of Salmonella spp. and Shiga toxin-producing $E$. coli. Int J Food Microbiol 2015, 208:11-18.

20. Di Pinto A, Novello L, Montemurro F, Bonerba E, Tantillo G: Occurrence of Listeria monocytogenes in ready-to-eat foods from supermarkets in Southern Italy. New Microbiol 2010, 33:249-252

21. Elviss NC, Little CL, Hucklesby L, Sagoo S, Surman-Lee S, de Pinna E, Threlfall EJ: Microbiological study of fresh herbs from retail premises uncovers an international outbreak of salmonellosis. Int J Food Microbiol 2009, 134:83-88.

22. Erkan M, Vural A: Investigation of microbial quality of some leafy green vegetables. J Food Technol 2008, 6:285-288.

23. Filiousis G, Johansson A, Frey J, Perreten V: Prevalence, genetic diversity and antimicrobial susceptibility of Listeria monocytogenes isolated from open-air food markets in Greece. Food Control 2009, 20:314-317.

24. Francis GA, O'Beirne D: Isolation and pulsed-field gel electrophoresis typing of Listeria monocytogenes from modified atmosphere packaged fresh-cut vegetables collected in Ireland. J Food Prot 2006, 69:2524-2528.

25. Gelbicova T, Karpiskova R: Occurrence and characteristics of Listeria monocytogenes in ready-to-eat food from retail market in the Czech Republic. Czech J Food Sci 2009, 27:3-7.

26. Graça A, Esteves E, Nunes C, Abadias M, Quintas C: Microbiological quality and safety of minimally processed fruits in the marketplace of southern Portugal. Food Control 2017, 73:775-783.

27. Graça A, Santo D, Esteves E, Nunes C, Abadias M, Quintas C: Evaluation of microbial quality and yeast diversity in fresh-cut apple. Food Microbiol 2015, 51:179-185.

28. Guerra MM, McLauchlin J, Bernardo FA: Listeria in ready-to-eat and unprocessed foods produced in Portugal. Food Microbiol 2001, 18:423-429.

29. Gunel E, Kilic GP, Bulut E, Durul B, Acar S, Alpas H, Soyer Y: Salmonella surveillance on fresh produce in retail in Turkey. Int $J$ Food Microbiol 2015, 199:72-77.

30. Johannessen GS, Loncarevic S, Kruse H: Bacteriological analysis of fresh produce in Norway. Int J Food Microbiol 2002, 77:199-204.

31. Kłapeć T, Cholewa A, Cholewa G, Dutkiewicz J, Wójcik-Fatla A: Microbiological characterization of vegetables and their rhizosphere soil in Eastern Poland. Ann Agric Environ Med 2006, 23:559-565.

32. Kovacevic M, Burazin J, Pavlovic H, Kopjar M, Pilizota V: Prevalence and level of Listeria monocytogenes and other Listeria spp. in ready-to-eat minimally processed and refrigerated vegetables. World J Microbiol Biotechnol 2013, 29:707-712.

33. Cekani ML, Malollari I, Makolli VL: Microbiological contamination of vegetable food as risk factor for human population. J Environ Prot Ecol 2014, 15:764-770.

34. Little CL, Barrett NJ, Grant K, McLauchlin J: Microbiological safety of sandwiches from hospitals and other health care establishments in the United Kingdom with a focus on Listeria 
monocytogenes and other Listeria species. J Food Prot 2008, 71:309-318.

A large survey study conducted in the UK.

35. Meldrum RJ, Ribeiro CD, Smith RMM, Walker AM, Simmons M, Worthington D, Edwards C: Microbiological quality of ready-toeat foods: results from a long-term surveillance program (1995 through 2003). J Food Prot 2005, 68:1654-1658.

36. Meldrum RJ, Smith RMM, Ellis P, Garside J: Microbiological quality of randomly selected ready-to-eat foods sampled between 2003 and 2005 in Wales, UK. Int J Food Microbiol 2006 108:397-400.

37. Moreno Y, Sanchez-Contreras J, Montes RM, GarciaHernandez J, Ballesteros L, Antonia Ferrús M: Detection and enumeration of viable Listeria monocytogenes cells from ready-to-eat and processed vegetable foods by culture and DVC-FISH. Food Control 2012, 27:374-379.

38. Nousiainen LL, Joutsen S, Lunden J, Hanninen ML, FredrikssonAhomaa M: Bacterial quality and safety of packaged fresh leafy vegetables at the retail level in Finland. Int J Food Microbiol 2016, 232:73-79.

39. Omurtag I, Smulders FJM, Hilbert F, Paulsen P: Microbiological condition of chicken doner kebab sold in Vienna, Austria. Arch Lebensmittelhyg 2012, 63:142-146.

40. Ozpinar $\mathrm{H}$, Turan B, Tekiner IH, Tezmen G, Gokce I, Akineden O: Evaluation of pathogenic Escherichia coli occurrence in vegetable samples from district bazaars in Istanbul using realtime PCR. Lett Appl Microbiol 2013, 57:362-367.

41. Robertson LJ, Johannessen GS, Gjerde BK, Loncarevic S: Microbiological analysis of seed sprouts in Norway. Int J Food Microbiol 2002, 75:119-126.

42. Rodriguez $M$, Valero A, Carrasco E, Perez-Rodriguez F Posada GD, Zurera G: Hygienic conditions and microbiological status of chilled ready-to-eat products served in Southern Spanish hospitals. Food Control 2011, 22:874-882.

43. Sadler-Reeves L, Aird H, de Pinna E, Elviss N, Fox A, Kaye M

- Jorgensen F, Lane C, Willis C, McLauchlin J: The occurrence of Salmonella in raw and ready-to-eat bean sprouts and sprouted seeds on retail sale in England and Northern Ireland. Lett Appl Microbiol 2016, 62:126-129.

A large survey study conducted in the UK.

44. Sagoo SK, Little CL, Mitchell RT: The microbiological

- examination of ready-to-eat organic vegetables from retail establishments in the United Kingdom. Lett App/ Microbiol 2001, 33:434-439.

A large survey study conducted in the UK.

45. Sagoo SK, Little CL, Mitchell RT: Microbiological quality of open ready-to-eat salad vegetables: effectiveness of food hygiene training of management. J Food Prot 2003, 66:1581-1586.

46. Sagoo SK, Little CL, Ward L, Gillespie IA, Mitchell RT: Microbiological study of ready-to-eat salad vegetables from retail establishments uncovers a national outbreak of salmonellosis. J Food Prot 2003, 66:403-409.

47. Santos MI, Cavaco A, Gouveia J, Novais MR, Nogueira PJ, Pedroso L, Ferreira MASS: Evaluation of minimally processed salads commercialized in Portugal. Food Control 2012, 23:275-
48. Schwaiger K, Helmke K, Hoelzel CS, Bauer J: Comparative analysis of the bacterial flora of vegetables collected directly from farms and from supermarkets in Germany. Int $J$ Environ Health Res 2011, 21:161-172.

49. Sireli UT, Guecukoglu A: Prevalence and antibiotic resistance of Listeria spp. isolated from ready-to-eat foods in Ankara. Turk Vet Anim Sci 2008, 32:131-135.

50. Skockova A, Karpíková R, Koláčková I, Cupáková : Characteristics of Escherichia coli from raw vegetables at a retail market in the Czech Republic. Int J Food Microbiol 2013 167:196-201.

51. Soderqvist K, Lambertz ST, Vagsholm I, Boqvist S: Foodborne bacterial pathogens in retail prepacked ready-to-eat mixed ingredient salads. J Food Prot 2016, 79:978-985.

52. Szymczak B, Dabrowski W: Effect of filling type and heating method on prevalence of Listeria species and Listeria monocytogenes in dumplings produced in Poland. J Food Sci 2015, 80:1060-1065.

53. Terzi G, Gucukoglu A, Cadirci O, Uyanik T, Alisarli M: Serotyping and antibiotic susceptibility of Listeria monocytogenes isolated from ready-to-eat foods in Samsun, Turkey. Turk J Vet Anim Sci 2015, 39:211-217.

54. Vojkovská H, Myková P, Gelbíčová T, Skočková A, Koláčková I, Karpíková R: Occurrence and characterization of food-borne pathogens isolated from fruit, vegetables and sprouts retailed in the Czech Republic. Food Microbiol 2017, 63:147-152.

55. Wagner M, Auer B, Trittremmel C, Hein I, Schoder D: Survey on the Listeria contamination of ready-to-eat food products and household environments in Vienna, Austria. Zoonoses Public Health 2007, 54:16-22.

56. Wijnands LM, Delfgou-van Asch EHM, Beerepoot-Mensink ME,

- van der Meij-Florijn A, Fitz-James I, van Leusden FM, Pielaat A Prevalence and concentration of bacterial pathogens in raw produce and minimally processed packaged salads produced in and for The Netherlands. J Food Prot 2014, 77:388-394.

A very comprehensive microbiological survey study.

57. European Centre for Disease Prevention and Control: Annual Epidemiological Report 2015 - Shigatoxin/VerocytotoxinProducing Escherichia coli Infection. Stockholm: ECDC; 2016.

58. European Centre for Disease Prevention and Control: Annual Epidemiological Report 2015 - Listeriosis. Stockholm: ECDC; 2016.

59. European Centre for Disease Prevention and Control: Annual Epidemiological Report 2015 - Salmonellosis. Stockholm: ECDC; 2016.

60. Semenza JC, Herbst S, Rechenburg A, Suk JE, Höser C, Schreiber C, Kistemann T: Climate change impact assessment of food and waterborne diseases. Crit Rev Environ Sci Technol 2012, 42:857-890.

61. EFSA: Scientific opinion on the risk posed by pathogens in food of non-animal origin. Part 1 (outbreak data analysis and risk ranking of food/pathogen combinations). EFSA J 2013.

62. Kulas M, Porto-Fett ACS, Swartz RS, Shane LE, Strasser H, Munson M, Shoyer BA, Luchancky JB: Thermal inactivation of shiga toxin-producing Escherichia coli cells within veal cordon bleu. J Food Saf 2015, 35:403-409. 